\title{
Analysis on the Development of Producer Services in China-Based on Intermediate Demand of Three Industries
}

\author{
Yong Yang \\ Guangdong Institute of Scientific and Technical Information, Guangzhou, China \\ Email: victoryangy@163.com
}

Received 20 April 2015; accepted 22 June 2015; published 26 June 2015

Copyright @ 2015 by author and Scientific Research Publishing Inc.

This work is licensed under the Creative Commons Attribution International License (CC BY).

http://creativecommons.org/licenses/by/4.0/

(c) () Open Access

\begin{abstract}
From the intermediate demand perspective of the industry, agriculture and services, this paper analyzes the problems on the development of producer services in China and gives some related causes. To accelerate the development of producer services in an even better fashion, we think the following measures should be taken: developing the high-end manufacturing and promoting the interaction between manufacturing and producer services; attaching equal importance to imported technology and independent innovation; improving the promotion and training for agricultural technology and optimizing agriculture production structure; developing the modern service industry; enhancing the supplying quality of producer services.
\end{abstract}

\section{Keywords}

Producer Services, Intermediate Demand, Development

\section{Introduction}

The demand of producer services held a greater proportion in service demand and service trade. In the early 1990s, the proportion of intermediate demand services had been around 50\% in service stock in developed countries [1], and intermediate demand services became the main driving force of a country or regional economic development. Especially along with the rapid development of economic globalization in recent years, the proportions of service input for industry, agriculture and services are continually increasing, and producer services have been the leading force and main content in the globalization. Accelerating the development of pro- 
ducer services contributes to maintaining the competition position of China during it engages in the globalization. From the perspective of intermediate demand, this paper aims to analyze the causes of the development of producer services in China and its existing problems, and propose some suggestions to accelerate the development of producer services.

\section{The Pulling Effect of Intermediate Demand on Producer Services and Its Development Trend}

\subsection{The Pulling Effect of Intermediate Demand on Producer Services}

No matter in the sense of economic, employment or society, nowadays many developed countries in the world have entered the era of "service economy". Baumol (1976) viewed this phenomenon that the influence of services had exceeded agriculture and industry as the inflation of employment that brought with related low productivity services sector, and regarded it as the appearance of "cost disease" [2]. Even other scholars doubted about the effect of service economy on the economic growth from various perspectives, e.g. "industry hollowing", "deindustrialization", etc., it's undeniable that western developed countries kept the leading and dominant status in the structure of world wealth even if their economic growth rate were lower than emerging economics. Many scholars, such as Baumol (1967); Rostow (1960); Fuchs (1968); Bell (1974) and Chenery \& Syrquin (1986) attributed the Petty-Clark phenomenon that with the economic development, the proportion of primary industry decreased gradually, while the proportion of secondary industry increased first and then decreased, and the tertiary industry held the greater proportion and contribution in economy to the ultimate demand of services activities [2]-[6]. In other words, they thought the ultimate demand of services activities strengthened the status of western development countries in the structure of world wealth. However, the demand factors which are merely based on Engel's theorem have some limitations in explaining the changing of industrial structure, while the intermediate demand which reflects the technology change and deepening of division of labor gives the supplementary explanation to the dynamic development of industrial structure in detail. The rapid accumulation of wealth was achieved by technology change and deepening of division of labor [7]. In terms of China, the new path of industrialization characterized by "high technology, better economic benefits, less pollution to environment and human resources advantages are fully used" not only promotes the growth of gross domestic product (GDP), but also generates powerful pulling effect on the intermediate demand of producer services.

The general experience of economic development in many western developed countries in the world showed that services played an important role in the nation economy. Even though the proportion of services decreased slightly during the period of industrialization, the developing pace of producer services kept with the industry development [8]. And during the period of "post-industrial society", those producer services that represented the expanding intermediate demand in the industrial production had more significant and greater growth than other service sectors.

\subsection{The Development Trend of Intermediate Demand of Producer Services}

In terms of the development trend of intermediate demand of three main industries to the producer services, taking the input-output table of the developed countries, e.g. the U.S.A., Britain, Japan, German, France, etc. from 1960s to the late of 1990s as examples, the intermediate demand from tertiary industry itself increased significantly while the intermediate demand from primary industry and secondary industry decreased obviously [9] [10]. For an instance, in the U.S.A., Britain, and Japan in the late of 1990s, the intermediate demand from services industry had exceeded the sum of intermediate demand from the primary industry and secondary industry, and the rate of intermediate demand in German and France was even higher. These results were consistent with the findings of Cheng's research (2008) on intermediate demand of producer services in 13 OECD countries [11]. With the back-flow of manufacturing in European and American countries and the implement of re-industrialization in these countries in recent years, predictably the intermediate demand from secondary industry will increase greatly. Additionally, according to the input-output table of China in 1987, 1990, 1992, 1995 and 2000, the rate of intermediate demand in service sectors showed a stable increasing trend [12]. Unlike the development trend of the intermediate demand of services in western countries, the rate of intermediate demand in three main industries in China showed increasing trend in different extent, but the overall level was not high. According to the research findings of Li \& Pan [13], in the view of direct consumption coefficient of primary industry, secondary industry and tertiary industry to the tertiary industry from 1987 to 1995, the direct consumption coeffi- 
cient of primary industry to the tertiary industry in China ranged from 0.03 to 0.06 , even if it was in an increasing trend but still far below the same indictor in the U.S.A (0.154), Japan (0.089), and Britain (0.121). The direct consumption coefficient of secondary industry to the tertiary industry was hovering from 0.08 to 0.13 (see Table 1), which was lower than the same indicator in U.S.A in 1967 (0.144) and Japan in 1980 (0.134). The dependence of secondary industry to the tertiary industry was hovering from $11 \%$ to $18 \%$, which was lower than $25.2 \%$ for the U.S.A and $19.7 \%$ for Japan [14]. The complete consumption coefficient of tertiary industry to itself was in the medium level compared to the other industry in China, ranging from 0.2 to 0.3 and in increasing trend. This indicator showed no significant difference to Japan and the U.S.A. (0.3).

If China sets the amount of intermediate demand of producer services in OECD countries as its development goal, a conclusion can be made as this: The intermediate demand of three main industries to the producer services all are in the increasing trend and the three main industries rank by the rate of input of producer services from high to low is: tertiary industry, secondary industry, and primary industry. In details, the growth rate of intermediate demand of primary industry and secondary industry to the producer services is lower than the tertiary, while the growth rate of intermediate demand of primary industry to the producer services is lower than the secondary.

\section{The Main Problems in Developing Producer Services in China and Its Causes}

Since over 20 years ago, China has been aware of the development of services industry, especially the producer services have momentous impact on the society and country in several aspects, e.g. promoting employment, expanding the consumption, upgrading the industrial structure, reducing the resource consumption, and strengthening the long-term development ability etc. In addition, in 1992, the Central Committee and the State Council (CPC) introduced formally the "Decision of The Central Committee of The Communist Party of China and The State Council on Accelerating Development of Tertiary Industry". However, to this day, the development of producer services in China is still in a slow pace. And there are some causes which may give explanations about it as following.

\subsection{The Backward Industrial Production Mode Leaded to the Insufficient Demand to Producer Services}

In Reference [15], Jiang \& Liu investigated the input rate of producer services in the manufacturing industry from 1997 to 2002 in China, and found that industries required more intermediate demand of producer services were capital-intensive industries and technology-intensive industries, e.g. the food manufacturing and tobacco processing industry, nonmetal mineral product industry, paper printing and educational and sports products manufacturing, common machines and special equipment manufacturing, electric equipment and machinery manufacturing, etc. However, in recent 10 years, with the increasing outward-oriented degree of China, the rate of intermediate demand of these industries to producer services was decreasing. For an example, in the electric equipment and machinery manufacturing, the rate of intermediate demand to producer services dropped from $16.58 \%$ in 2002 to $14.09 \%$ in 2005 , which meant nearly $86 \%$ of the input to this industry were tangible material elements.

The detailed causes mainly embodied in the following ways. Firstly, under the mode of outward-oriented economy of China and the national conditions of that time, Chinese manufacturing firms merged in the process of globalization as the international original equipment manufacturer (OEM) by processing with materials or given samples, assembling supplied components and got the development of space by relying on low cost of labor and land. At the meantime, this production pattern leaded to the overdevelopment of labor-intensive industries at the low value added level in the industrial chain. Even if in the new circumstances of transformation and upgrading at present, a rather large number of firms still employ the traditional production pattern, which

Table 1. The direct consumption coefficient of the primary and secondary industry to tertiary industry in China.

\begin{tabular}{ccccccc}
\hline Industry & 1987 & 1990 & 1992 & 1995 & 2000 & 0.0622 \\
Primary industry & 0.0365 & 0.0363 & 0.0597 & 0.0572 & 0.0794 \\
Secondary industry & 0.0843 & 0.0812 & 0.1326 & 0.1047 & 0.1028 \\
\hline
\end{tabular}

Source: Reference [14]. 
is characterized by domestic firms seldom engage in activities at the high-end in the modern industrial chain or activities require firm's core competence, e.g. R \& D and design of products, brand management and marketing, etc. While the producer services for these activities are provided by the headquarter office of multinational corporation in home country, or by branches introduced by foreign direct investment (FDI), the intermediate demand of domestic producer services is extremely limited. Moreover, these manufacturing firms pay less attention to financial services, R\&D and design, information technology and customer services, which suppress the scale and level of intermediate demand of domestic producer services in China as well as restrain the domestic producer services to develop toward the higher levels. Research on the international OEM mode in China since the reform and opening has found that the international OEM mode impeded the industrial linkage between the manufacturing firms and services firms, and leaded to slow development of producer services due to lack of sufficient demand.

Secondly, because of the backward development of industries in various regions, and aims to utilize the foreign capital to develop local economy and obtain low profit, various regions offer "zero cost" even "zero premium" to attract foreign capital in the competition. These measures lead to intensity the passive state in the international industrial division. Moreover, as the fierce competition causes the high transaction cost and low transaction efficiency, industrial firms are unable to break through and improve the factor endowment gradually through the evolution of division of producer services in the regional system. Further, the intermediate demand of producer services has been reduced, which makes a vicious circle.

\subsection{Farmers' Low Income and Education Level Lead to the Insufficient Demand of Agricultural Producer Services}

On one hand, from the perspective of supply of agricultural producer services, farmers have strong demand for the agricultural producer services, especially for the productive techniques and the agricultural science and technology service provided by agricultural technicians [16]. But for a long time, the main function of agricultural science and technology service system led by government were to achieve the technology popularization tasks made by government at various levels, seldom paid attention to the demand of farmers, and then leaded to low efficiency in agricultural producer services [17].

On another hand, from the perspective of demand of agricultural producer services, there exist some related problems. In terms of the personal factors of farmer, low education of farmers leaded to their narrow knowledge about the agricultural producer services and its effect on promoting the development of modern agriculture. As results, the farmers were accustomed to applying the traditional farming methods, and then the demand of producer services decreased. From the point of view of family factor, the annual per capita net income of rural household in China in 2012 was 7916.6 RMB yuan. Taking off the inflation of prices, children education expenditure and increasing living cost, the remaining disposable income of rural household of China was rather low and rural household lack of ability to pay,especially in the central and western regions. And the rural households adopt the decentralized operation instead of large-scale operation, which results in insufficient demand of farmer to agricultural producer services. This viewpoint is similar to Fouratie's [18]. Besides, from the perspective of regional factors, even if in countryside, farmers who lived in the nonagricultural area had less demand of agricultural producer services, e.g. farmers who lived in the eastern coastal area had less demand of agricultural producer services than those who live in the central and western regions.

\subsection{The Insufficient Development of Services Industry Limits Producer Services "Self-Strengthening"}

Goe (1990), Juleff (1996) and Pilat \& Wolfl (2005) found that in developed countries, the greatest demand to producer services was from services sectors, instead of manufacturing sectors [19]-[21]. In other words, the service industries had the effect of "self-strengthening". In different stages of economic development, the demand to producer services was different. In agricultural society, since the level of science and technology was not high, the traditional family organization mode required little producer services. In the period of industrial society, especially in the middle stage of industrialization, industries had been the domain role in the nation economy. With the pace of industrialization went forward, the demand of industries to producer services was increasing continuously. However, when the economic development passed the stage of industrialization and the proportion of services in the nation economy was becoming greater, those finance, telecommunication, and business service which served for industries in the past time also be required by other services sectors. Thus, the proportion of 
intermediate demand of producer services in the nation economy increased. In the era of "service economy", the intermediate demand of services to the producer services rises increasingly; even exceeds the intermediate demand of industries to the producer services (see Table 2). Thus, the "self-strengthening" mechanism formed in producer services. For example, in 2007, the rate of intermediate demand of services to producer services in the U.S.A. was $68.5 \%$, which was greater than China's $34.2 \%$ in the same period (as Table 3 shown). This suggests that with the arrival of knowledge economy, the development of services itself and its demand to the producer services will be the main driving force for the development of producer services.

Table 2. The comparison of complete consumption coefficient of intermediate demand to services for one unit product.

\begin{tabular}{|c|c|c|c|}
\hline Industries & $\mathrm{A}^{\mathrm{a}}$ & Industries & $\mathrm{B}^{\mathrm{b}}$ \\
\hline Business & 0.0961 & Business & 0.0819 \\
\hline $\begin{array}{l}\text { Electric power, steam and } \\
\text { hot water production and supply }\end{array}$ & 0.0664 & $\begin{array}{l}\text { Electric power, steam and } \\
\text { hot water production and supply }\end{array}$ & 0.0600 \\
\hline Freightage and storage & 0.0498 & Social services & 0.0587 \\
\hline Finance and insurance & 0.0364 & Finance and insurance & 0.0410 \\
\hline Social services & 0.0342 & Freightage and storage & 0.0400 \\
\hline Postal service & 0.0180 & Construction & 0.0244 \\
\hline Catering industry & 0.0145 & Postal service & 0.0207 \\
\hline Construction & 0.0068 & Passenger transportation & 0.0174 \\
\hline Polytechnical services & 0.0068 & Catering industry & 0.0174 \\
\hline Real estate & 0.0054 & Real estate & 0.0105 \\
\hline Passenger transportation & 0.0044 & Tap water production and supply & 0.0084 \\
\hline Tap water production and supply & 0.0035 & $\begin{array}{l}\text { Education, culture, art as well as } \\
\text { Broadcasting, movie and television }\end{array}$ & 0.0081 \\
\hline $\begin{array}{l}\text { Education, culture and art as well as } \\
\text { Broadcasting, movie and television }\end{array}$ & 0.0032 & Polytechnical services & 0.0080 \\
\hline Hygienism, sports and social welfare & 0.0011 & Gas production and supply & 0.0040 \\
\hline Scientific research & 0.0008 & Scientific research & 0.0018 \\
\hline Gas production and supply & 0.0007 & Hygienism, sports and social welfare & 0.0015 \\
\hline Business & 0.0961 & Business & 0.0819 \\
\hline
\end{tabular}

a: Row A is the complete consumption coefficient of intermediate demand to services for one unit industrial product. b: Row B is the complete consumption coefficient of intermediate demand to services for one unit service product. Sources: The input-output table of China in 2007and the input-output table of the U.S.A in 2007.

Table 3. The proportion of intermediate demand of services to other industries in China and the U.S.A. in 2007.

\begin{tabular}{|c|c|c|}
\hline \multirow{2}{*}{ Industry } & \multicolumn{2}{|c|}{ Percentage } \\
\hline & China & the U.S.A. \\
\hline Input of agricultural and mineral resources & $3.3 \%$ & $0.7 \%$ \\
\hline Intermediate input of manufacturing & $48.5 \%$ & $16.7 \%$ \\
\hline Input of producer services & $34.2 \%$ & $68.5 \%$ \\
\hline Water, electricity, gas and construction & $4.9 \%$ & $8.8 \%$ \\
\hline Input of other services & $9.1 \%$ & $5.3 \%$ \\
\hline
\end{tabular}

Source: The input-output table of China in 2007 and the input-output table of the U.S.A in 2007. 


\subsection{The Poor Quality of Producer Services Reduced the External Demand}

According to the statistic of World Bank, in recent years, the proportion of added value in tertiary to GDP has been over $70 \%$ in general in high income countries. For the middle-income countries and the low-income countries, the proportion was around $60 \%$ and $45 \%$, respectively. However, that proportion in China was less than $45 \%$ in the same period. Even though by 2013 , that proportion in China was $46.1 \%$. This situation was related to the lagging development of producer services, e.g. the $\mathrm{R} \& \mathrm{D}$ and design in manufacturing and key technologies were dependent on import. Moreover, in the international division system, the entry of foreign capital to the demand of specialized services would lead to the growth of producer services in some extent. And there are two restraining factors about it.

The first one is the links in the division chain and status of host-country. The higher levels in the industrial division chain require the more specialized intermediate demand services, while the lower levels in the industrial division require less intermediate demand services [14]. Since 1992, China government has attached great importance to the development of producer services. Even though the producer services in China has made great progress in the recent 20 years, the development of producer services is still at a low level. Therefore, the poor quality of producer services weakens its effect on strengthening the base for industrial transformation and upgrading in China. Besides, a great number of research institutes, universities, and headquarter of firms cluster at the large cities, and there are less leading firms to promote the development of producer services in non-urban or rural areas. Thus, the unbalanced space distribution of producer services increases the cultivating cost of producer services.

The second one is when the foreign capital has been restricted to enter into the services and the cost of delivering services via international service trade and via remote mode is lower than the cost of entering into services of host-country, the headquarter office of multinational corporation will provide or purchase various services and deliver the services via remote mode. As results, the serving function of producer services in industrial division will be weakened [22]. In addition, China serves as the "world factory" in the international specialization and takes charge of manufacturing works in the industrial chain, which causes a great demand of producer services spill over to foreign countries and influence the demand to domestic producer services.

\section{The Suggestions for Developing the Producer Services in China}

In 2008, the industrial development in some regions of China was drawn in the dilemma due to the global financial crisis. How to cope with the financial crisis effectively? How to conduct the transformation and upgrading and lay the foundation for sustainable development? These questions are critical issues for China on its way to build up the innovative country. Accelerating the construction of modern industrial system and optimizing the industrial structure should be the core in the period of transformation and upgrading. And speeding up the development of producer services is not only the key measure to strengthen this core but also top priority in economic development in China.

Based on above arguments about the demand of producer services, and the reality of increasing demand of producer services in China, we believe that it's necessary to foster and stimulate the efficient demand of society to producer services. In other words, the pre-condition to speed up the development of producer services is that society not only has the demand to producer services but also has the ability to pay. Thus, two key questions appear: How to improve the ability to pay for the producer services? How to transform the potential demand to the real demand? In order to enlarge the demand to producer services, we attempt to propose some suggestions for policy makers as follows.

\subsection{Develop the High-End Manufacturing, and Strengthen the Industrial Interaction between Manufacturing and Producer Services}

The merchandise structure was determined by both the industrial structure of manufacturing and producer services. In order to improve the leading role of trade to producer services, except to develop the producer services, the most essential measure is to enhance the industrial interaction between manufacturing and producer services. As the upstream industry of manufacturing, the producer services are highly depending on manufacturing. On one hand, the level and the degree of specialization of manufacturing determine the level and the developing speed of producer services. That is, the high degree of specialization leads firms are more likely to remove the producer services from inside and turn to use the services provided by professional service outsourcing firms, 
e.g. various business services (professional law, accounting and auditing services), market services (advertising, market survey, consulting), and technology services (R\&D and product design) etc. [23]. On another hand, the level of producer services also determines the level of manufacturing. Therefore, developing the high-end manufacturing and boosting the implement of knowledge economic project should promote the development of high-end producer services. When the advantages of clustering of producer services form gradually in one region, this region owns comparative advantage to other regions. As a result, the cross regional demand becomes one of the driving forces of regional development.

\subsection{Attach Equal Importance to Imported Technology and Independent Innovation}

Since the reform and opening of China in late of 1970s, in order to import foreign capital and technology to develop the economy, China has made preferential treatment for foreign-invested firms for a long time. Relaying on the advantage of low cost of labor and land, most of regions in China have achieved rapid growth by working as OEM. However, the policy of preferential treatment for foreign-invested firms led to the extensive growth in foreign direct investment and low-end manufacturing, dragging China to fall into the comparative advantage trap [14]. As a result, the manufacturing mode of China stayed at the low-end of international industrial chain, and the intermediate demand to producer services was limited. Hence, it's necessary to attach the equal importance of imported technology and independent innovation. On the one hand, China should selectively import the foreign capital, e.g. the foreign capital with high-tech valve, and introduce the foreign capital invest to weak links in industries, agriculture and services as well as to the central and western region and the northeast region. The policy of government should pay more attention to the role of the agency of producer services which facilitates the technology transfer from foreign countries to China and cooperation between the foreign firms and Chinese firms. On the other hand, China government should set about to adjust and optimize the industrial structure, improve the capability of independent innovation. In the environment of opening economy, Chinese firms need to strengthen their capability of independent innovation, and upgrade the manufacturing mode from OEM to original brand manufacture (OBM) and original design manufacture (ODM) gradually. Besides, giving support to multinational corporations that operate in both international market and domestic contributes to enlarging intermediate demand to the producer services.

\subsection{Enhance the Agricultural Technology Promotion and Training and Adjust the Production Structure in Agriculture}

The agricultural technology promotion and training has been influenced to some extent due to Chinese farmers' income are relatively low and their limited knowledge as well as the poor condition of agricultural technology services system. The further behind of the development of agriculture cause the less demand to the agricultural science and technology services, and vice versa. Therefore, the administration departments of government ought to increase the investment in agricultural technology services system, and improve the working condition for agricultural technicians. Besides, aims to widen farmers' knowledge of agricultural technology services, the agricultural technology training can be carried out via various forms, e.g. training course, telecourse, publications, exhibitions and consulting etc.3 Furthermore, the China government has advocated to develop family farm in recent years. By firstly supporting the regional agricultural firms conduct the large-scale agricultural projects, the government should encourage and guide the operator of family farm to produce production of "high yield, good quality, and high economic benefits". In this process, related producer services, e.g. the cooperative research, financial and insurance support, and equipment leasing services, help to solve the difficulties and the problems in developing the family farm. For the low-value agricultural products, agricultural subsidies can be provided for manufacturers by government to meet their intermediate demand to producer services.

\subsection{Make Great Effort in Developing the Modern Service Industry}

The reform and opening of China in late 1970s broke through in the agriculture at first. In 1984, the focus of reform moved to restructuring the state-owned enterprises gradually, while the reform of services was lagging for a long time. Even though after China joined in the World Trade Organization in 2001, the service industries in China still confronted the institutional difficulties in its developing path. Therefore, it's urgent to impel the reform of services in China. And making great effort in developing modern service industry is the most impor- 
tant issue in the reform. The pilot reform of replace the business tax with the value-added tax should be implemented in all areas of services and the tax, financial funds and subsidies should serve as the support for development of modern services. Besides, the China government ought to: (1) break up the obstacles for accessing markets, e.g. market segmentation, trade monopoly and regional restriction; reducing administrative examination and approval; (2) utilize the investment policy instruments to attract various capital to make investment on the modern services; (3) establish and perfect the financial and land policy for developing modern service industry; (4) implement the human resources development strategy; and (5) facilitate the division and cooperation between service sectors. The focal points of development modern services including service sectors such as R\&D and design, the third party logistics, information and technology services, energy saving and environment protection services, certification and inspection services, electronic business, consulting, outsourcing, customer services, human resource services and brand building, etc. [24].

\subsection{Improve the Quality of Producer Services}

Along with the tertiary has replaced the secondary industry as the largest economic sector in China, the driving effect of service economy to nation economy become significant increasingly. Nevertheless, in the environment of global competition, the quality of producer services of China is still at a low level. In order to keep the advantageous status in the competition, improving the quality of producer services and innovating the serving mode are crucial tasks for China. The quality of services including some aspects: the service means, service efficiency, the length of service time, and the service level. The improvement of service quality can stimulate the growth of services [25]. This requires the supplier of producer services to improve the response speed and meet the individualized demand in time. At the same time, the government ought to accelerate the process of standardization in various services sectors, e.g. logistic, finance, postal services, telecommunication, transportation, tourism, sports, trade, etc. For the emerging producer service sectors, the leading firms, local government and the industry associations should cooperate to formulate the service standard together. And for the service sectors which can't be standardized at present, the innovative service mode, e.g. the service commitment, service criterion, etc., can be popularized widely. The above measures are significant to improve the quality of producer services. For the face to face service mode, reinforcing the word-of-mouth marketing helps to provide the real information of products for the potential customers. By this means, the gap between customer's expectation and service perception can be reduced. For the management practices, it's vital to improve the quality of producer services by introducing the external participants, e.g. increase the interaction with customer in the service process. In addition, training for the staffs of producer services supplier is an effective way to improve the quality of producer services.

\section{Conclusion}

China has become the world's second largest economy since 2011, and its great development potential of producer services should be the powerful driving force for its economy growth in the future. From the perspective of intermediate demand of three industries to producer services, there exist some problems in the development of producer services in China. The causes of these problems have been analyzed from various aspects, e.g. lowend manufacturing mode, insufficient external demand and the low development quality. Accordingly, some suggestions and measures to accelerate the development of producer services for Chinese firms and government have been put forward. With the implement of these suggestions, the author believes that China will catch up with the developed countries with a faster speed in the process of economic globalization.

\section{Funding}

This research was supported by the Key Project of Philosophy and Social Sciences Research, Ministry of Education of China "Research on Accelerating the Development of Producer Services in China” (11JZD023).

\section{References}

[1] Grubel, H.G. and Walker, M.A. (1989) Service Industry Growth: Cause and Effects. Fraser Institute, Montreal.

[2] Baumol, W. (1967) Macroeconomics of Unbalanced Growth: The Anatomy of Urban Crisis. American Economic Review, 57, 415-426. 
[3] Rostow, W.W. (1960) The Stages of Economic Growth: A Non-Communist Manifesto. Cambridge University Press, Cambridge.

[4] Fuchs, V.R. (1968) The Service Economy. National Bureau of Economic Research, Cambridge, Mass.

[5] Bell, D. (1974) The Coming of Post-industrial Society. Heinemann Educational Books Ltd., London.

[6] Chenery, H.B., Robinson, S. and Syrquin, M. (1986) Industrialization and Growth: A Comparative Study. Oxford University Press, New York.

[7] Sayer, A. and Walker, R. (1992) The new Social Economy: Reworking the Division of Labor. Blackwell, Oxford.

[8] Riddle, D. (1986) Service Led Growth: The Role of the Service Sector in the World Development. Praeger Publishers, New York.

[9] Wei, Z.L. (2009) Research on Development Strategies of Chinese Service Industry. Economic and Scientific Press House, Beijing.

[10] Li, W.X., Li, J.F. and Chen, L. (2009) The Comparative Analysis on the Structure of Service Industry between China, America, and Japan. Modern Management Science, 6, 40-42.

[11] Cheng, D.Z. (2008) Development Level, Structure, and Impact of Producer Services in China: An International Comparison Based on Input-Output Approach. Economy Research, 1, 76-88.

[12] Zhou, Q.X. and Tong, W.W. (2005) The Explanation to the Changing Trend of the Rate of the Third Industry’s Intermediate Demand in China. Journal of Shanxi Teachers University (Social Science Edition), 32, 45-47.

[13] Li, J.F. and Pan, F.L. (2001) The International Comparison of the Consumption Coefficient and Dependence in Tertiary Industry. Macroeconomic Study, 5, 56-60, 63.

[14] Zheng, K.J. (2008) Factor Analysis on the Intermedia Demand of Chinese Service Industry Development—Features of Intermediate Demand and Industrial Division Development. Journal of Shanxi Finance and Economics University, 2, 47-55.

[15] Jiang, J. and Liu, Z.B. (2010) Can Orientation to Workshop of the World Promote China’s Producer Services Development? Economic Theory and Economic Management, 3, 62-68.

[16] Xu, J.H. (2009) Research on the Demand Willingness of Farmers to Agricultural Science and Technology Services and Its Impact Factors-The Case of Jiangsu Province. Economic Review, 10, 62-64.

[17] Hu, R.F., Huang, J.X. and Li, L.Q. (2004) The Promotion of Agricultural Technology in China: The Situation, Problems, and Solutions. World of Management, 5, 50-57, 75.

[18] Fouratie, J. (1949) The Great White Hope of the XXth Century. PUF, Paris.

[19] Goe, W.R. (1990) Producer Service, Trade and the Social Division of Labor. Regional Studies, 24, $327-342$.

[20] Juleff, E. (1996) Advanced Producer Services: Just a Service to Manufacturing. The Service Industries Journal, 16, 389-400. http://dx.doi.org/10.1080/02642069600000035

[21] Pilat, D. and Wölfl, A. (2005) Measuring the Interaction between Manufacturing and Services. OECD Science, Technology and Industry Working Papers, No. 2005/05, OECD Publishing, Paris.

[22] Beyers, W.B. and Lindahl, D.P. (1996) Explaining the Demand for Producer Services: Is Cost-Driven Externalization the Major Factor? Papers in Regional Science, 75, 351-374. http://dx.doi.org/10.1007/BF02406758

[23] Jiang, X.J. and Li, H. (2004) Service Industry and China’s Economy: Correlation and Potential of Faster Growth. Economy Research, 1, 4-15.

[24] The State Council of P.R.C. (2014) The Guidance on Accelerating the Development of Producer Services to Promote Industrial Restructuring and Upgrading. http://www.gov.cn/zhengce/content/2014-08/06/content_8955.htm

[25] Xiao, W. and Fan, W.J. (2011) The Development of the Producer Services Industry in Industry Association-A Study Based on Demand Scale and Demand Structure. Economist, 6, 72-80. 